\title{
Colombia For Export: Johanna Ortiz, Pepa Pombo and the re-creation of the cultural identity for a global fashion market
}

\section{Beltran-Rubio, Laura}

\section{Abstract:}

In a moment in time when Colombia seems to be entering a postconflict state after over six decades of violence, Colombian nationals are engaging in the reconstruction of a national identity, especially through cultural production. Colombian fashion designers, creating one of the most visible images of identity -clothingare an essential part of this process of re-creation of the nation. In this paper, I study the ways in which Johanna Ortiz and Pepa Pombo, two important Colombian designers that are widely known both in the country and abroad, selling their products through high-end international fashion retailers, use traditional elements of the national identity to create a new image of

\section{Cuadernos del Centro de Estudios de Diseño y Comunicación Nº 64}

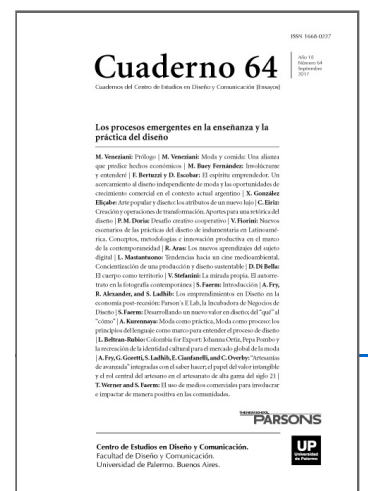

ISSN: 1668-0227

Los procesos

emergentes en la

enseñanza y la

práctica del diseño

Año XVIII, Septiembre 2017, Buenos

Aires, Argentina | 326 páginas

\section{ver índice de la publicación}

Ver todos los libros de la publicación

compartir en Facebook

Colombia, as the basis of their creations for export. I study how Johanna Ortiz takes inspiration from the orchid, national flower, and the elements of traditional costume, and how Pepa Pombo borrows hand-woven techniques of textile manufacture and geometric, abstract and tribal patterns in textile design from the indigenous communities. I argue that, in de-constructing the stereotypes that associate these elements with the violent and corrupt ideas of armed conflict and drug cartels, and reinterpreting them in their own design aesthetic, they reconstruct the Colombian nation and re-create the national identity under a positive light, thus providing a new image of Colombia both for export and for the Colombian peoples to identify with.

Key words:

Fashion - design - national identity - Colombia - Johanna Ortiz - Pepa Pombo - orchid - indigenous craft.

(*) Studied Economics at the Universidad de Los Andes in Bogota, Colombia, and received her MA in Fashion Studies from Parsons School of Design. Her work brings together economic history, art history and fashion 
history and theory to study the creation of identity through fashion and cultural production.

\section{Introduction}

One of the greatest problems Colombia has faced from the moment it became an independent nation in the first half of the nineteenth century has been the creation of a national identity. Despite the different attempts and mechanisms to construct a cohesive identity to unite the peoples that inhabit the national territory, led mostly by the intellectual elites of the country, the Colombian identity is inherently fractured and regionalized. The mixed society of the country and the co-existing cultural values resulting from it, has created a variety of imagined communities (Anderson, 2006) in the different regions of the country, rather than allowing for the construction of social and cultural ideals and norms that are shared by everyone in the nation. Moreover, the exaggerated attention to guerrillas, drug cartels and corruption seems to have done nothing more than intensifying the inherently fractured Colombian national identity, altering the cultural values of the nation and creating an atmosphere not only of violence and intolerance but also of illegality, corruption, and easy-profiteering. However, as recent efforts in peacemaking and the civilized negotiation of a Peace Agreement between the government and the Colombian Revolutionary Armed Forces (FARC) have shown, Colombia seems ready to face a new effort in the construction of a national identity away from the stereotypical attention to wars and drugs. Different agents within the country are actively searching for a way in which to re-construct the national identity, both internally and externally, and producing a new set of values around which to recuperate a positive attitude towards the country, based on shared cultural values that stand away from those of violence and corruption. This process of reconstruction, beyond the efforts of the intellectual elites and governmental leaders, includes the participation of the broader public, in which popular culture, the arts, and all the elements that conform the cultural patrimony of the nation, play an essential role (Suárez, 2008, p. 406). Among these new sources of national identification, fashion has acquired an essential character, as it has helped the nation not only to re-structure itself in the eyes of its inhabitants, but mostly because it has re-shaped the ways in which the country is seen by outsiders, from an international perspective. This paper analyzes the particular case of two Colombian fashion designers, Johanna Ortiz and Pepa Pombo, who have engaged in the re-construction of the national identity through their creations, many of which are marketed to an international public and sold to a variety of customers abroad. By engaging in a visual analysis of some of their designs, I study the ways in which Johanna Ortiz and Pepa Pombo re-construct the Colombian national identity to create garments that appeal to the fashionable consumer of Europe and the United States. Johanna Ortiz, on one hand, re-constructs some of the most important symbols of national identity, including the orchid, which is the Colombian national flower, and the elements shared by many styles of Colombian traditional garments in order to create her international fashion brand. With these designs, Johanna Ortiz manages to step away from the "narco" ideal of beauty that, emerging from the drug cartels of the eighties, has persisted in the country until today; she re-shapes the notion of "narco" femininity and converts it into a sensual, elegant and cosmopolitan ideal of femininity, thus re-constructing the nation in her designs. Pepa Pombo, on the other hand, borrows inspiration from the textiles created by indigenous communities, to highlight the participation of the indigenous peoples in the construction of the Colombian national identity. Despite being constantly forgotten by Colombian nationals and abandoned by the government, the indigenous heritage is an important part of Colombian identity, and it acquires a central in the creation of the national identity that Pepa Pombo re-creates in the designing of world-class fashionable garments. Far from the exploitative idea of the indigenous peoples who engage in architectural practices only to supply for the drug trafficking network of the country, Pepa Pombo positions the imagery associated with their textile designs as an essential element of her 
design aesthetic and elevates it to a world-class, fashionable sense of feminine elegance. Before studying these ideas in-depth, I begin my paper by understanding the important role of fashion in the creation of a national identity, borrowing ideas from the work of scholars of different fields, including Roland Barthes, Angel Rama, Homi Bhabha, Stuart Hall, and Caroline Evans. Their ideas are essential in the shaping of my analysis, through which I view culture as a fluid concept, which is always under transformation, and which can be given meaning through fashion, which is, on itself, a language and network of signs. With these ideas in mind, I study Johanna Ortiz's Resort 2016 collection, in which she creates garments inspired on the Colombian national flower, the orchid, while destructing the ideas of femininity and certain flowers, like the amapola, used to make heroine, only to re-construct them in the creation of a Colombian national identity away from violence and drugs. I then study Pepa Pombo's Fall/Winter 2016 collection, as a representation of the brand's design aesthetic that has developed over the past forty years, both in the hands of Pepa Pombo herself and her daughter and new creative director of the firm, Mónica Holguín. This collection, I argue, shows how Pepa Pombo appropriates knitwear, one of the most important manufacturing techniques for the indigenous peoples, as well as the aesthetic of many textile designs elaborated by the Chibcha peoples, which included naturalistic and stylized, geometric, and abstract patterns. Her work, I argue, re-positions the indigenous peoples at the forefront of cultural production in the country, while recreating the Colombian national identity by giving them the importance they deserve, rather than neglecting them -as both the Colombian people and its government tend to do- or subjugating them to the hands of violence and the production of illegal drugs. I finalize this paper with some concluding thoughts.

\section{Fashion and national identity}

As early as the eighteenth century, Latin American societies realized the importance of clothing in the creation of an identity. With the intense process of miscegenation that took place during the Colonial period, the Latin American societies of the late-eighteenth century became increasingly mixed-raced, and differences of race and status through skin color were blurred. Dress thus became an essential mechanism to establish difference in rank and dressing habits acquired a central role in the shaping of social norms and identity. As the Latin American societies adopted a modern bourgeois model of organization and their economies began to grow, thus allowing for people of different ranks to accumulate wealth, the appropriation of dress styles belonging to different ranks became easier. Clothing became, then, a threatening element in the societies of the late-eighteenth and earlynineteenth centuries, as it could enable people from lower sectors to look like their social superiors (Meléndez, 2005). Dress, therefore, as one of the clearest visual characteristics of personality, became an increasingly important mechanism to show one's identity: how one dressed had a direct relationship with the self, and one could reveal details about social status, gender, even morality, through the characteristics of dress (Meléndez, 2005). Practices of dress and the discourses on fashion surrounding them became "an important component of culture, crucial to the micro-order of daily life .... and crucial to one's relationship with self and others" (Entwistle, 2000, p. 77). Dress thus acquired a protagonist role in shaping many societies from around the world as early as the eighteenth century -and possibly even before, with the many precedents that the Renaissance established for modernity. Moreover, dress became a means of communication, through which one could show to the world not only their social identity and rank, but also the set of cultural norms and beliefs that were associated to such an identity. The idea of dress as a means to communicate identity is, in many ways, rooted in Roland Barthes' (1973; 1990; 2013) analysis of fashion as a language. Building on semiology, which was introduced by Ferdinand de Saussure (1960), Barthes studies fashion within a verbal or written realm, and sees clothing as a contained sign system in which a garment can convey a particular meaning when placed in a 
specific context. The meaning of clothing, he claims, is communicated through a process of signification, where the garment can be understood as a sign with two constituent parts: the physical signifier and the mental processes that reveal what is signified. In the context of a contemporary economy, as Caroline Evans explains, the meanings of this language of fashion can be re-created; fashion becomes

...part of a network of signs, of which the actual garment is but one... It is because the commodity form is evolving that we can talk about fashion signifying in a new way, as part of the circulation of signs and meanings in the global economy... (Evans, 2013, p. 96)

Fashion, therefore, can be used to create and re-create meanings in an increasingly globalized economy, where the circulation of signs includes all the images and alternative meanings that surround the garment, as well as the commoditization of fashion itself. This idea is particularly important in my study of Johanna Ortiz's and Pepa Pombo's designs, as it recognizes the changes in the meanings of symbols that can be articulated through the language of fashion. By using, in their design aesthetic, specific elements of the Colombian national identity that tend to be unrecognized by the international consumers whose view of Colombia falls into the stereotyped ideas of guerrillas and drug cartels, I argue, Johanna Ortiz and Pepa Pombo designers create new meanings for the Colombian national identity through the symbolism of their designs. However, these meanings would not be effectively understood and would not become essential in the re-construction of the Colombian national identity if they were not accompanied by a whole network of signs that includes the attention to their designs by retail giants such as Moda Operandi and Bergdorf Goodman, by magazines such as W and Harper's Bazaar, or even by star bloggers and mavens of social media. As both language and network of signs, fashion can be used in the creation of identity, which, as Zimmermann (1998) claims, exists within the coherence between appearance and being, and is constructed in time. In the case of a nation, Ernest Renan (1995) explains, identity is founded on a "heroic past, great men, glory [which are] the social capital upon which one bases a national idea" that are constructed in the process of "narrating the nation" as a cultural product (Bhabha, 1995). The construction of a national identity is thus built upon the virtue of permanence of signs through time (Rama, 1998) and, as Eric Hobsbawm (2004) explains, often relies on "invented traditions", whose main purpose is to provide continuity of a new reality with a suitable historic past and emerge within a dateable period and establish with great rapidity. In the creation of a nation, which Anderson explains is imagined, limited, and a community, "nation-ness" is a cultural artifact that can be transplanted self-consciously in a variety of political and ideological contexts. Because a national identity cannot be remembered, Anderson (2006) proposes, it must be narrated in a homogeneous and empty time, where the imagined community acquires a historical frame and a sociological setting. As such, the national identity creates a cultural imaginary that, unrecognized and taken for granted, comprises the set of beliefs, norms and expected behaviors for people in the society, shapes life and gives it both meaning and purpose, and structures the characteristics of the nation that will be seen by both insiders -the Colombian peoples- and outsiders (Lakies, 2010, p. 500). This notion of a cultural imaginary, as well as that of the imagined community that shapes around it, are extremely important in the study of fashion as a cultural product: they reflect the idea, constantly explored in the field of fashion studies, that fashion is dependent on the interactions between individuals in a society. Fashion does not emerge exclusively from the existence of a garment, but results from the interaction of that garment with a body and, simultaneously, with other garments and other bodies in the social context in which it exists. Moreover, the set of shared norms and values that compose the cultural imaginary that underlies the imagined community or the narrated nation, can be created through the language of fashion, through the garments created by fashion designers of the country, and through the 
meanings that they, as signs and symbols that form a language on itself, convey. The creation of an identity through the construction of an imagined community and a cultural imaginary also imply that, especially in cultural terms, identity is not a fixed or accomplished fact. Regarding this matter, Stuart Hall (1990) explains that (cultural) identity is always being produced, always under construction, and always created within the realm of representation (p. 222). The (cultural) identity is to be framed around both being and becoming (or what Susan Kaiser (2012) terms "Who I am/Who I am becoming") and, as such, is in constant transformation: despite being somehow rooted in history, identity reflects the interplay of the past and the future, of history, power and culture (Hall, 1990). Fashion, as a visual language that can create and reproduce certain meanings that relate to a particular set of cultural and social norms shared by a group of people, is essential in the creation of a cultural imaginary and an imagined community, thus acquiring an important role in the creation of a national identity. But this national identity is fluid and constantly under construction, so that the meanings associated with its symbols, as well as the symbols themselves, can change over time. This aspect of identity, as well as the important of fashion as a visual language to create identity, are central to my study of Johanna Ortiz's and Pepa Pombo's designs: the elements of the Colombian national identity they include in their visual language of fashion construct a very specific idea of the Colombian nation, which is strikingly different to the violent and corrupt stereotypes that have emerged from the exaggerated attention given to guerrillas and drug cartels. In providing the international fashion market with these elements of the Colombian national identity through their designs, Johanna Ortiz and Pepa Pombo are, I argue, re-shaping this national identity in the eyes of the world and, perhaps more slowly, re-constructing the Colombian nation in the eyes of its peoples. By making elements of the Colombian national identity central to their designs, Johanna Ortiz and Pepa Pombo create their brands for what Francesco Morace (1993) calls "archetypal consumption". Morace highlights the importance of communication and the creation of an imaginary in the production and marketing of fashion in the global market: contemporary fashion brands create a story around their products in order to encourage their consumption. In archetypal consumption, he argues, the main focus of this imaginary, of the story told by a brand, lies in the nation of origin of the fashionable products the brand creates. The archetypal consumption of fashion, therefore, becomes an expression of cult that revolves around the place of origin of the product -as occurs with the widely known case of the cult to the "Made In Italy". Moreover, the ways in which Johanna Ortiz and Pepa Pombo re-construct the Colombian national identity are not independent of a wider movement in which the country is attempting to reconstruct itself, and reflect the anxieties of a generation. In this sense, the fashion designs created by Johanna Ortiz and Pepa Pombo lie within what Walter Benjamin (1999) called the "dialectical theatre of fashion," which lies in that it can refabricate the old while looking forward, in its capacity to reverberate in time, while reflecting a truth that is fleeting and temporal. Building on dress aesthetics from the Colombian past -traditional garments in the case of Johanna Ortiz and indigenous traditions in the case of Pepa Pombo- these two designers are projecting the Colombian nation into the future. They are, as Caroline Evans (2013) puts it, "stretch[ing] simultaneously back to the past and forward into the future" (p. 107), and creating new ideas and meanings of the Colombian national identity. Johanna Ortiz and Pepa Pombo, I argue, are using the images of the past conveyed in their designs to make sense of the present moment in Colombian history, to remind Colombians of what their nation 'originally' looked like, without the exaggerated attention to wars and drugs, and to teach outsiders what Colombia really is, thus creating a new discourse around the Colombian nation which will be carried into the future.

Johanna Ortiz: creating a cosmopolitan nation 
On 26 March 2015, Johanna Ortiz went global with the launch of her trunk show with high fashion online retailer Moda Operandi, taking her outside of the Colombian national barriers into an increasingly globalized fashion world (Leon, 2015). A few months later or, as an editor of Harper's Bazaar put it, "A follow on Instagram, a Resort pre-sale on Moda Operandi, and that top all over social media later" (Pieri, 2015) and fashion lovers of the United States were obsessed with the poplin off-the-shoulder top that positioned Johanna Ortiz's self-proclaimed "feminine, effortlessly elegant" style in the eyes of the international fashion sphere. Using the increased attention that fashion and social media have brought to her brand, and building her design aesthetic around some of the most important symbols of the Colombian national identity, I argue, Johanna Ortiz re-fabricates this identity and re-constructs the ideal of feminine beauty in the country, thus re-creating the Colombian national identity both to the eyes of Colombians and to the eyes of outsiders viewing the country from abroad. Born in Cali, Colombia, Johanna Ortiz studied fashion design at the Art Institute of Fort Lauderdale. Upon her return to her home country, she started designing beachwear and providing style advice to her friends, before establishing her eponymous label and creating her now world-famous couture garments. Having grown up in Colombia, "surrounded by its tropical landscapes, dramatic mountains, and its huge variety of plants, birds" (Pieri, 2015), the designer takes inspiration from the geographic and natural diversity of the country. But her design style, as can be clearly seen in the nature of her creations and the immense appeal they have to a global market, is also international. She often takes inspiration from Parisian women, from menswear, from the elegant, feminine sensuality of the fifties (Pieri, 2015). Being inspired by both Colombia and global fashions, Johanna Ortiz's designs have a distinctive style that negotiates the traditional cultural identity of Colombia with a more European sense of aesthetics, thus reconstructing the Colombian identity as a product for export. Her Resort 2016 collection is the main focus of my analysis, not only because it was sold by Moda Operandi and featured in the famous windows of retail giant Bergdorf Goodman on Fifth Avenue in New York City, but also because it is the first one that overtly takes symbols of national identity and re-constructs them in the creation of her own language of fashion. After designing a collection based on the 1920s' 'garçonne' style and one inspired on the Japanese technique of Origami, Ortiz constructed her Resort 2016 collection around the orchid, Colombia's national flower. The overall aesthetic of the collection reveals the characteristics of the flowers in the vibrant colors chosen to create the garments, some of them even including floral prints in the material used. Moreover, the use of ruffles, which have become a staple ingredient of Ortiz's design style, makes a clear allusion to the undulating petals of orchids. These ruffles are, in many cases, made with several layers of fabric sewn together, creating a hard texture that even resembles that of orchid petals, which are thicker and harder than those of many other flowers. Finally, the symmetry of the ruffles and, in general, of the design aesthetic in many of the garments of this collection, recalls the almost perfect symmetry that characterizes the orchid itself. The use of ruffles, so important in Ortiz's design aesthetic, also makes a direct allusion to the Colombian national identity beyond orchids: they are an essential characteristic of the many different variations of traditional costume. Emerging as a product of the miscegenation that took place in the country during the Colonial period, the Colombian traditional costume was originally worn by mestizos (mixed-race peoples) in the countryside. The female dress consists of an off-the-shoulder top with ruffles and an accompanying pollera, a long skirt, often with ruffles at the bottom, which can take up as much as 3-5 meters in its construction (Museo de Trajes Regionales). In warm-weather regions, such as Johanna Ortiz's native Cali, the fabric of choice for these costumes is often muslin or poplin, and they are often made with colorful fabrics and adorned with embroideries of contrasting hues. The size of the ruffles and the fullness of the pollera depend on the region and the intended use of the costume, with ceremonial costumes being more colorful and ornamented than those worn by countryside mestizas on their everyday life. This type of dress, although now worn mostly for special festivities such as the religious carnivals of San Juan and San Pedro, and the several 
carnivals and "ferias" that take place throughout the country, is one of the most important visual stereotypes of Colombian clothing and the national identity that is attached to it. The colorful duo of ruffled off-the-shoulder top and pollera is also often worn by the "Palenqueras" selling fruits in the historical center of Cartagena, an image that would be instantly recognized virtually by every fashion lover of today, as the city has gained the increased attention of international 'fashionistas,' especially through the eyes figures like Lauren Santo Domingo and websites like Refinery 29. Johanna Ortiz uses ruffles as the most visual characteristic in her designs for tops, skirts and dresses, making an allusion to the Colombian traditional costume, that is reinforced by her choice of poplin for the construction of most of her designs. Although the shapes she creates are very distinctive from the traditional costume, their presence near the neckline and on the bottom of skirts can be considered as a direct reference to the traditional costume. Her best-selling 'Tulum top' -the "poplin, off-the-shoulder top with dramatic balloon sleeves" that made the editors at Harper's Bazaar swoon- for instance, is a clear example of her appropriation and re-creation of national dress in her designs. But, by naming it after the Mexican fashionable destination of Tulum -instead of Cartagena, or even her native city of Cali, for example- she places it within an international market and in the mind of a cosmopolitan, well-traveled consumer. A brief survey of fashion tastemakers from around the world confirms Tulum's place as the capital of fashionable vacationers, with even Revolve Clothing setting a summer home in 2015, and hosting parties to which only the most influential fashion bloggers were invited and exhorted to inundate social media with images of the city. As a result, Johanna Ortiz's re-creation of the Colombian national identity in her designs turns the country into a globalized, cosmopolitan, and highly fashionable, elegant capital and wanderlust destination. This cosmopolitan, Europeanized elegance that Johanna Ortiz promotes in her designs contrasts strikingly with the image of feminine beauty that was constructed and spread throughout the country by drug cartels. Her sleek figures and simple designs, adorned by only the amount of color and ruffles that is strictly necessary to give her garments a slight touch of fashionable personality, contrasts with the voluptuous nature, often achieved through plastic surgery, of the "narco" type of Colombian beauty and the ostentatious, extremely tight, often over-the-top clothing that would half-dress their bodies. In fact, Ortiz heavily criticizes the tight dresses that would hug the bodies of these women to emphasize their curves, which have become a staple of feminine style in the country (Pieri, 2015). By promoting a new type of femininity, one that is almost built in opposition to the "narco" beauty created by the voluptuousness of women encouraged by male leaders of drug cartels, Johanna Ortiz creates a new notion of Colombian femininity, one that appeals not only to the international fashion market, but also to the Colombian women that are starting to identify with the style promoted by young Colombian designers like her, slowly adopting a more cosmopolitan, less sexualized, and more elegant sense of fashion and style.

But Johanna Ortiz's re-creation of a national identity away from drugs and the internal armed conflict between the government and guerrilla groups that is so closely related to it, is also present in the use of floral patterns and the names of flowers in her Resort 2016 collection. Not only is the orchid the protagonist, but the amapola (or poppy) and bougainvillea, common to the tropical landscapes of the country and Ortiz's hometown Cali, are also featured. The amapola is particularly important because it is the raw material for the creation of heroine, perhaps one of the most addictive and dangerous drugs. But Johanna Ortiz provides an image of the amapola that stands far away from its connotation to heroine, and places it under the sleek, simple elegance of her design aesthetic; she makes a reference to the flower itself, instead of the dangerous result of the drug created with the highlyprocessed plant. Moreover, the native Colombian flowers, like the amapola and the bougainvillea, coexist in her collection with a wide variety of flowers, including the cherry blossom, so often identified with Japan, and the bergamot, symbol of Paris in some occasions, placing her vision of Colombia seamlessly next to a variety of 
other countries, thus constructing the national identity as globalized and international. Once more, Johanna Ortiz is creating a cosmopolitan, elegant version of Colombia away from the violence and corruption that have resulted from the armed conflict and the drug cartels, both for consumption abroad and for identification within the country.

Pepa Pombo: modernizing the indigenous craft

"Intricate hand-woven skirts are the recognizable pieces to buy into this season", claims the text accompanying Pepa Pombo's Fall/Winter 2016 pre-sale in Moda Operandi, promoting the "still relatively new to the US market... family business specializing in luxury knitwear and renowned throughout Latin America for its heritage". In fact, even though Pepa Pombo is considered perhaps the most important fashion designer in Colombia, her designs are relatively new to the United States fashion market. The first time a Pepa Pombo collection was sold on Moda Operandi happened only recently, and a second high-end fashion retailer in New York, Fivestory, will only begin to carry her products from July 2016. Pepa Pombo, however, started designing over 40 years ago. Her design aesthetic, building garments using knitted and hand-woven textiles, both traditions inherited in Latin America from the indigenous peoples, is an identifier of Colombian high-end fashion, known both inside the country and throughout the region, especially in Mexico. The use of knitwear, so essential in Pepa Pombo's designs, is her main asset in the re-construction of a Colombian national identity, which has, so often, focused more on the mixed-race ideal of a 'whitened' mestizo than on the rich cultural heritage left by the indigenous peoples. By making knitwear central to her designs, and by including motifs inspired on indigenous textiles, Pepa Pombo reconstructs the Colombian national identity as a more inclusive, mixed, society, rather than the 'whitened' construction left by the Spanish heritage and promulgated by the country's elites. Pepa Pombo was born in Bogota, capital district of Colombia, although she lived most of her childhood and adolescence in Peru. After she graduated in Fine Arts from the Universidad de los Andes, in Bogota, and moved to Mexico, only to fall in love with the country and its culture, and to start her eponymous fashion brand (Cromos, 2010). The couture garments she designs use tridimensional forms in the textile design, as well as a wide variety of colors and textures, borrowing inspiration from some of the most important aspects of indigenous craft. Although this language has been present in Pepa Pombo's designs during the decades she has been active, and continue to be exploited by Mónica Holguín, the designer's daughter and new creative director of the brand, my analysis focuses on the Fall/Winter 2016 collection, the first to be sold by several highfashion retailers in different parts of the world, and a very clear representation of the main characteristics of Pepa Pombo's design style. The collection, despite using the indigenousinherited hand-woven techniques so traditionally used by Pepa Pombo, includes a set of garments that are in high-demand among the fashion lovers of the world: from off-theshoulder tops to maxi-skirts, and from cropped jackets to high-waist flare pants. As many of her previous collections, this one includes a variety of printed, geometric, naturalistic and "tribal" patterns, and is made entirely with hand-woven fabrics, which allows me to study it as an accurate representation of what has become her staple fashion style throughout the decades. These patterns, as well as the use of hand-woven textile-making techniques, are a direct reference to indigenous craft and textile design. One of the most advanced groups of indigenous peoples in Colombia upon the arrival of the Spanish conquistadores were the Chibcha peoples, who lived in the central region of the country, occupying the territory of what are nowadays the departments of Cundinamarca (including the capital city, Bogota), Boyacá, and Santander. Their economy centered around agriculture, and they engaged, as many of the indigenous peoples of the time, in the exchange of goods with nearby communities. From this exchange, the Chibcha peoples acquired gold and cotton from which they developed textiles, using some of the most advanced hand-weaving and knitting techniques of their times to produce cotton fabrics and mantles that would protect their 
bodies from the cold weather in which they inhabited (Melo, 1996). The textiles produced by the Chibcha peoples were highly ornamented and featured both naturalistic patterns and stylized motifs, inspired on simplified representations of nature. Most of these motifs emerged from the Chibcha view of the natural world that surrounded the community, including the variety of animals and plants, as well as human beings, within their mythology. However, they were often simplified to a great extent, to the point in which they became almost totems representative of their mythology. For example, the bird, one of the most important natural beings in their mythology, often identified with their Sun god, could be represented by a couple of striped triangles or a circle inside a larger one (Jiménez de Muñoz, 2009). These simplified motifs, as well as the geometric and abstract patterns so often seen in Chibcha textiles, are used in many of Pepa Pombo's designs, and conform a central part of her design techniques. For example, some of the textile designs in the Fall/Winter 2016 collection include a seamless pattern of lozenges with smaller lozenges in the center, different variations of abstract floral patterns, a tri-dimensional pattern made up of strips of rectangles and triangles, and a more figurative pattern with colored flowers. All of these, at least indirectly, allude to the motifs used by the Chibcha and other indigenous communities in the country, although the symbolic meanings that the motifs once held have now been lost. It is important to note, however, that Pepa Pombo does not mention the indigenous heritage of her brand explicitly, nor does she copy actual Chibcha textiles. Rather, she creates the products on her own, with clear visual references to an indigenous aesthetic but without pretending to place her product as one of indigenous creation. In doing so, Pepa Pombo avoids the exploitation of the indigenous peoples in a capitalist fashion market, one that, in many ways, seems not to be too far away from the exploitative system of production that characterizes the drug trafficking industry, in which the indigenous peoples and other Colombian countrymen are subjugated in order to harvest the raw materials for the production of drugs. Instead of exploiting indigenous craft, I believe, Pepa Pombo elevates it in the construction of world-class fashionable garments catered to the European and United States' taste, thus re-constructing the national identity beyond the traditional stereotypes that tend to describe it. Without naming the indigenous peoples as her source for inspiration, Pepa Pombo continues the process of construction of a nation that is clearly mixed-raced but, by including the visual aesthetic of indigenous textiles in fashionable garments that are made for consumption both in the country and abroad, she highlights the importance of the indigenous peoples in the construction of the Colombian national identity -importance that was officially neglected before 1991, when the political constitution finally recognized the indigenous peoples were officially named Colombian citizens, and which continues to be disregarded, with 18 peoples (out of 87) in danger of extinction (ACNUR). Pepa Pombo de-constructs the idea of the exploited indigenous peoples working forcibly - even if only by the need of profits that selling plants such as the coca or the amapola to the drug trafficking industry will bring them- for the drug cartels; she de-constructs the idea of the indigenous heritage forgotten by the nation and neglected by the state. Instead, Pepa Pombo re-constructs the national identity with the indigenous peoples at its forefront, thus recognizing the importance of the inclusion of different races in the Colombian identity. For, as can be seen in its peoples, Colombia is a clearly mixed society, and in order to construct a national identity away from violence and drugs, the factors that unite it, rather than those that fragment it, need to be highlighted. And, in one way or another, most of the nation now descends from the indigenous peoples -if only because the territory now comprised by the nation, home to contemporary Colombians, once belonged to them.

\section{Conclusions}


In this paper, I have studied the ways in which Johanna Ortiz and Pepa Pombo re-create the Colombian national identity through their fashion designs. National identity, as I see it, is a fluid concept, always under construction, that forms out of the invented traditions that narrate a nation and create an imagined community with a shared set of norms and values that unite its peoples. And, although Colombians have tried to construct this identity from the moment of their independence, first declared in 1810, it continues to be, over two hundred years later, fractured and incomplete. However, as the country moves towards the signing of a Peace Agreement between the government and the revolutionary armed forces, moving into a transitional post-conflict after over 60 years of violence, new efforts towards the unification of the Colombian peoples and the creation of a true national identity have emerged. In their creation, cultural production has taken a crucial role, and fashion design has become a key element towards the construction of a national identity. The work of fashion designers, such as the young, emerging Johanna Ortiz and the established, more traditional Pepa Pombo, is an essential aspect of this process. In this paper, I argue that Johanna Ortiz and Pepa Pombo re-construct the Colombian national identity to create garments that appeal to the fashionable consumer of Europe and the United States. Johanna Ortiz reconstructs the orchid, one of the most important symbols of national identity, to create a sleek, subtly feminine design aesthetic that appeals to the cosmopolitan fashionable consumer, while Pepa Pombo borrows inspiration from the textiles created by indigenous communities and positions them at the forefront of her design aesthetic, despite producing garments that, elegant and trendy, appeal to the international fashionable customer as well. Both designers, I have shown, manage to recreate a notion of the Colombian national identity in the eyes of both Colombians and the outside world, based on values that are strikingly different to the stereotypical notions of violence, drugs and corruption created by the exaggerated attention to the armed conflict and the drug cartels in the country. Fashion theorist Caroline Evans fluently argues that "Fashion images, like emblems or metaphors, are by their very nature densely packed with meanings which may be both complex and contradictory. Their interpretation is inevitable marked by the author's subjectivity" (Evans, 2013, p. 100). The fashion images created in Johanna Ortiz's and Pepa Pombo's designs are also intensely charged by the complexity of their meanings in the language of fashion and can convey a wide variety of significations, depending on the point of view from which they are looked at. But, because our interpretation of them is shaped by their authors, by Johanna Ortiz and Pepa Pombo themselves, they will, in one way or another, carry the meanings of a Colombian national identity that they convey; they will, to the variety of fashionable consumers that see them around the world, show an idea of Colombia that is completely different to the stereotype of violent guerrillas and corrupt drug cartels. In transmitting these messages around the world, in de-constructing the stereotypes that exist around Colombia to construct a new, fresh view of the country, they engage in the creation of a new national identity, perfectly in time for the postconflict that is about to start, with the signing and (hopefully) adoption of the Peace Agreement between the government and the revolutionary armed forces. And this creation of a national identity, from different perspectives and based on contemporary cultural production, including fashion, is an important way to ensure a better future for the country. For, as Pepa Pombo herself explains, Colombia must take example from the Mexicans, whose "nacionalismo los ha llevado a ser grandes... Ellos creen en su cultura" (Cromos, 2010). This love for the cultural identity of a country, indeed, is what she, as well as other Colombian designers such as Johanna Ortiz, has focused on while developing their fashion style. This love, de-constructing the negative stereotypes around some Colombian symbols and re-constructing them around a more positive view in order to produce a new national identity, is an essential aspect of the cultural production of Johanna Ortiz and Pepa Pombo in their fashion designs; it is a creation of a new Colombia, of a Colombia for export, where the beauty of the country, rather than the terror of war and drugs, is protagonist. 
References

ACNUR. (n.d.) Pueblos Indígenas en Colombia. Retrieved from http://www.acnur.org/t3/ pueblosindigenas/pueblos-indigenas-en-colombia/. Anderson, B. R. O'G. (2006 [1983]). Imagined communities: Reflections on the origin and spread of nationalism. New York; London: Verso. Barthes, R. (1973). Mythologies. London: Paladin. Barthes, R. (1990). The fashion system (M. Ward \& R. Howard, Trans.). Berkeley: University of California Press. (Original work published 1967). Barthes, R. (2013). The language of fashion (A. Stafford \& M. Carter, Trans.). New York; London: Bloomsbury. Benjamin, W. (1999). The arcades project (H. Eiland \& K. McLaughlin, Trans.). Cambridge, MA; London: Harvard University Press. Bhabha, H. K. (Ed.). (1995). Nation and narration. New York; London: Routledge. Cromos. (2010, April 26). Pepa Pombo, con México en el corazón. Retrieved from http://www. cromos.com.co/personajes/perfiles/articulo-pepa-pombo-mexico-el-corazon. Entwistle, J. (2000). The fashioned body: Fashion, dress and modern social Theory. Cambridge: Polity Press. Evans, C. (2013). In Fashion cultures: theories, expectations and analysis. New York; London: Routledge. Gracia Pérez, F. (2011). Hijos de la Madre Patria: El hispanoamericanismto en la construcción de la identidad nacional colombiana durante la Regeneración (1878-1900). Zaragoza: Institución Fernando el Católico. Hall, S. (1990). Cultural identity and diaspora. In J. Rutherford (Ed.), Identity: Community, culture, difference (pp. 222-237). London: Lawrence and Wishart. Hobsbawm, E. Introduction: Inventing traditions. In E. Hobsbawm \& T. Ragner (Eds.), The invention of tradition (pp. 1-14) Cambridge: Cambridge University Press. Jiménez de Muñoz, E. (2009). La representación del ave símbolo del dios Sua: El dios Sol entre los Chibcha. Bogota: Fundación Universidad de América. Kaiser, S. (2012). Fashion and cultural studies. London; New Delhi; New York; Sydney: Routledge. Lakies, C. (2010) Challenging the cultural imaginary: Pieper on how life might live. In New Blackfriars, 91(1035), 499-510. Leon, S. (2015, March 26). Johanna Ortiz loves Lee Radziwill, loathes tight dresses. W. Retrieved from http://www.wmagazine.com/fashion/2015/03/johanna-ortiz-designercolombia/photos/. Meléndez, M. (2005). Visualizing difference: The rhetoric of clothing in colonial Spanish America. In R. A. Root (Ed.), The Latin American Fashion Reader (pp. 17-30). Oxford; New York: Berg.

Melo, J. O. (1996). Historia de Colombia: el establecimiento de la dominación española. Bogota: Presidencia de la República; Imprenta Nacional de Colombia. Retrieved from http://www.banrepcultural.org/blaavirtual/historia/hicol/indice.htm. Moda Operandi. (n.d.) Pepa Pombo: Fall Winter 2016. Retrieved from https://www. modaoperandi.com/pepa-pombo-fw16. Morace, F. (1993). Contratendencias: Una nueva cultura del consumo. Madrid: Editorial Celeste Ediciones. Museo de Trajes Regionales. (n.d.). Trajes Mestizaje 1850 - 1950. Retrieved from http:// museodetrajesregionales.com/exposiciones/mestizaje/. Pieri, K. (2015, August 5). Brand watch: Swooning for Johanna Ortiz. Harper's Bazaar. Retrieved from http://www.harpersbazaar.com/fashion/designers/a11711/johanna-ortizfashion/. Rama, A. (1998). La ciudad letrada. Montevideo: Arca. Renan, E. (1995). What is a nation? (Martin Thom, trans.). In H. K. Bhabha (Ed.), Nation and narration (pp. 8-22). New York; London: Routledge. de Saussure, F. (1960) A course in general linguistics. London: Peter Owen. Sommer, D. (1991). Foundational fictions: The national romances of Latin America. Berkeley; Los Angeles; London: University of California Press. Suárez, J. (2008). "En Átomos Volando": Transformaciones de la iconografía patriótica en la producción cultural contemporánea colombiana. In Revista Iberoamericana 74 (223), 405-422. Zimmermann, D. (1998). Identity, context and interaction. In C. Antaki \& Sue Widdicombe (Eds.), Identities in talk. London: Sage. 
En un momento en que Colombia parece estar entrando en un estado postconflicto después de más de seis décadas de violencia, los colombianos están participando en la reconstrucción de una identidad nacional, especialmente a través de la producción cultural. Los diseñadores de moda colombianos, creadores de una de las imágenes más visibles de la identidad -la indumentaria- son una parte esencial de este proceso de recreación del país. En este artículo, se estudia la forma en que Johanna Ortiz y Pepa Pombo, dos destacadas diseñadoras colombianas ampliamente conocidas tanto en el país como en el extranjero, comercializan sus productos a través de canales minoristas de moda internacionales, y utilizan elementos tradicionales de la identidad nacional para crear una nueva imagen de Colombia como la base de sus creaciones para la exportación. El artículo indaga acerca de la inspiración de Johanna Ortiz en la orquídea, flor nacional y en los elementos del traje tradicional colombiano; y cómo Pepa Pombo utiliza las técnicas de tejido manual en la fabricación de textiles y los patrones tribales geométricos y abstractos de las comunidades indígenas. En este artículo se sostiene que en la deconstrucción de los estereotipos que asocian estos elementos con las ideas violentas y corruptas de los conflictos y los carteles de drogas armados, y la reinterpretación de ellos en su propio diseño estético, se contribuye a la reconstrucción de la nación colombiana para volver a crear la identidad nacional bajo una luz positiva, proporcionando así una nueva imagen de Colombia, tanto para la exportación como para los pueblos colombianos que se identifican.

Palabras clave:

Moda - diseño - identidad nacional - Colombia - Johanna Ortiz - Pepa Pombo - orquídea - artesanías indígenas.

\section{Resumo:}

Num momento em que Colômbia parece estar entrando num estado pós-conflito depois de mais de seis décadas de violência, os colombianos estão participando na reconstrução de uma identidade nacional, especialmente através da produção cultural. Os designers de moda colombianos, criadores de uma das imagens mais visíveis da identidade -a indumentária- são uma parte essencial deste processo de re- criação do pais. Neste artigo, estuda-se a maneira em que Johanna Ortiz e Pepa Pombo, duas destacadas designers colombianas reconhecidas no seu pais e no exterior, comercializam seus produtos através de canais retalhistas de moda internacionais, e utilizam elementos tradicionais da identidade nacional para criar uma nova imagem de Colômbia como a base de suas criações para a exportação. O artigo indaga na inspiração de Johanna Ortiz na orquídea, flor nacional e nos elementos das roupas típicas colombianas, e como Pepa Pombo utiliza as técnicas de tecido manual na fabricação de têxteis e os padrões tribais geométricos e abstratos das comunidades indígenas. Neste artigo se sustenta que na deconstrução dos estereótipos que associam estes elementos com idéias violentas e corruptas dos conflitos e os cartéis de droga armados, e a re-interpretação deles no próprio design estético, se contribui à reconstrução da nação colombiana para criar novamente a identidade nacional com uma luz positiva, proporcionando uma nova imagem de Colômbia, tanto para a exportação como para os povos colombianos que se identificam.

Palavras chave:

moda - design - identidade nacional - Colômbia - Johanna Ortiz - Pepa Pombo - orquídea - artesanato indígena. 
Colombia For Export: Johanna Ortiz, Pepa Pombo and the re-creation of the cultural identity for a global fashion market fue publicado de la página 239 a página253 en Cuadernos del Centro de Estudios de Diseño y

Comunicación № 64 